\title{
Joint ecological, geographical and cultural approach to identify territories of opportunity for large vertebrates conservation in Mexico
}

\author{
Clarita Rodríguez-Soto ${ }^{1} \cdot$ Alejandro Velazquez $^{2}$ (D) \\ Octavio Monroy-Vilchis ${ }^{3}$ - Pricila Lemes ${ }^{4} \cdot$ Rafael Loyola $^{4}$
}

Received: 26 October 2016/Revised: 10 February 2017/Accepted: 12 March 2017

(C) Springer Science+Business Media Dordrecht 2017

\begin{abstract}
The objective of the present paper is to provide a holistic framework to delineate "territories of opportunity" where agrarian communities can manage areas to enhance the conservation of large vertebrates. The study was conducted Mexico, which is sociologically, culturally and ecologically complex, similar to other "megadiverse" countries. We conducted ensemble niche modeling of endangered top predators to define a set of large vertebrate species. Environmental attributes were used to perform three distance-based and two artificial intelligence-based algorithms. Socio-cultural attributes were included to depict agricultural communities with strong social government schemes and clear evidence of well-managed natural resources. Other socio-economic attributes such as land acquisition cost, human agglomeration and anthropogenic land use were included in the analysis. Scenarios were computed and displayed cartographically with the aid of a geographic information system. Results showed that the largest concentration of biodiversity converges on regions with large land cover persistence and high local governance, defined as potential willingness to engage in conservation actions. The cartographic areas identified
\end{abstract}

Communicated by Daniel Sanchez Mata.

This article belongs to the Topical Collection: Biodiversity protection and reserves.

Alejandro Velazquez

alex@ciga.unam.mx

1 Centro de Estudios e Investigación en Desarrollo Sustentable (Centre for Studies and Research in Sustainable Development), Universidad Autónoma del Estado México, Mariano Matamoros 1007, Universidad, 50130 Toluca, Mexico

2 Centro de Investigaciones en Geografía Ambiental (Centre for Research in Environmental Geography), Universidad Nacional Autónoma de México, Antigua Carretera a Pátzcuaro No. 8701 Col. Ex-Hacienda de San José de La Huerta, C.P. 58190 Morelia Michoacán, Mexico

3 Facultad de Ciencias (Faculty of Science), Estación Biológica Sierra Nanchititla, Universidad Autónoma del Estado México, Instituto Literario 100, Centro 50000 Toluca, Mexico

4 Conservation Biogeography Lab, Departamento de Ecologia (Department of Ecology), Universidad Federal de Goias, Goiania, GO, Brazil 
overlapped with current Mexican protected areas in only $2.7 \%$ of the country. Thus, conservation law enforcement in most of the country seems to be ineffective. Here we show that, in a number of territories, agrarian communities that have coexisted for millennia with umbrella species can be regarded as allies in biodiversity conservation. Results are discussed in the light of their relevance for future niche modeling, environmental policy design and implications for climate change.

\section{Keywords Biodiversity $\cdot$ Conservation $\cdot$ Hot spots $\cdot$ Governance $\cdot$ Mexico}

\section{Introduction}

Biodiversity depletion, as the first irrefutable indicator of the human footprint, gained worldwide public attention during the 1980s (Griffith et al. 1989; Noble and Dirzo 1997). Biodiversity loss is a local phenomenon with drastic global implications (Noss and Harris 1986). Unquestionably, biodiversity provides crucial goods and environmental services; among these, it may contribute significantly to ameliorating climate change, if conserved properly (Balmford 2002; Dirzo and Raven 2003; Balvanera et al. 2006). There have been many actions aimed at biodiversity conservation, such as a substantial increase in programs to protect species and habitat. Naughton-Treves et al. (2005a), for instance, clearly documented the significant increase in both number of protected areas (over 100,000 established) and surface area set aside for biodiversity conservation purposes (over 20 million $\mathrm{km}^{2}$ ). Nonetheless, biodiversity conservation efforts remain incomplete (Butchart et al. 2010). Disputes and controversies demonstrate the inefficiency of efforts to create protected areas (Bruner 2001; Rodrigues et al. 2004; Gaston et al. 2006). The need for greater protected areas is especially critical within megadiverse countries, where most biodiversity is harbored (Dirzo and Raven 2003; Miles and Kapos 2008, Sarukhán et al. 2015). These countries are also the most promising to buffer climate change in the long term (Skutsch et al. 2013). In fact, biodiversity conservation and climate change should be regarded as linked issues.

In the 1980s, criteria to guide conservation actions were based purely upon ecological principles (Shaffer 1981; Simberloff 1998). Data on population genetics, size and dynamics (Gilpin and Soul 1986) as well as distribution patterns and habitat conditions (Soulé 1985; Lande and Barrowclough 1987; Shaffer 1987; Guisan and Zimmerman 2000; Fahrig 2001) remain among the most critical data to identify key species and hot spots for specific habitats (http://www.iucnredlist.org/technical-documents/categories-and-criteria consulted in February 6, 2014). For decades, biodiversity conservation was regarded as a separate issue from culture (Tilman et al. 2001; Brechin et al. 2003). During the last two decades, this vision has changed as ecology has been challenged to bridge with social sciences (Berkes and Folke 1998). It is now clear that biodiversity conservation should be regarded as a management modality (Berkes et al. 2000; Velázquez et al. 2001; Brechin et al. 2003). The objective of management differs drastically among cultures (Loh and Harmon 2005), but, put simply, humans groups chose species and spaces to obtain goods and benefits that eventually lead to anthropogenic products via domestication (Diamond 2002) or territoriality (Jones and MacLeod 2004). As a consequence, for effective biodiversity conservation, research must unavoidably combine ecological, social and geographical frameworks (Bray and Velázquez 2009; Faleiro et al. 2013).

Currently available data and emerging tools provide an unprecedented platform to conduct analytical initiatives from a holistic multidisciplinary approach (ecological, social 
and geographical) that may help to fil gaps on biodiversity conservation (Elith et al. 2006; Phillips et al. 2006). In this contribution, we argue that hot spots (sensu Myers et al. 2000) should be redefined based upon challenges and failures recognized to date (Brooks et al. 2002; Rodrigues et al. 2004; Foley et al. 2005). Species assemblages, rather single species, sharing ecological constrains must be targeted (Simberloff 1998); underlying socio-cultural attributes such as indicators of governance and socioeconomic and political attributes (sensu Geist and Lambin 2002; Folke et al. 2005; Ostrom 2010), rather than only proximate ones such as roads and human population density, must be included in order to create positive synergies and alliances among stake(space)holders (Velázquez et al. 2003; Velázquez et al. 2009). Species assemblages and underlying socio-cultural attributes must be analyzed together in order to define territories (sensu Raffestin and Butler 2012), rather than habitats, that may best enhance biodiversity conservation in the medium and long term (Walker et al. 2004; Brooks et al. 2006). With the aim of including these kind of attributes, we analyzed trade-offs, to explore the costs of relaxing one attribute to achieve increases in another (Moffett and Sarkar 2006). To our knowledge, little research has been published using this approach to define territories for conservation purposes.

The objective of the present paper is to joint ecological, geographical and cultural attributes to identify territories of opportunity for large vertebrates' conservation in Mexico. Territories of opportunity are here defined as areas where legal and legitimate jurisdiction is recognized by local, regional and national stake(space)holders; in consequence agreements pacts and compromises aimed at implementing effective conservation are more likely. Furthermore, we discuss this concept in contrast to previous conservation actions and the likely implications of the outcomes in the light of current conservation efforts. The research was based on Mexico as a representative of megadiverse regions, as it is among the top five countries worldwide in terms of biodiversity richness (NaughtonTreves et al., 2005b; Sarukhán et al. 2015), and it has a high level of socio-cultural complexity (Ávila-Blomberg 2008; García-Frapolli et al. 2009). Furthermore, Mexico has made substantial efforts to enhance biodiversity conservation, for instance, increasing the number and surface area of established protected areas (Fuller et al. 2007), and it harbors one of the most remarkable biodiversity databases in the world (Soberón et al. 2007; Sarukhán et al. 2008). Yet effective conservation has proved insufficient (Mas 2005; Figueroa and Sánchez-Cordero 2008; Bray et al. 2008).

\section{Methods}

\section{Ecological niche models}

We targeted a set of large vertebrate species to build an assemblage of large vertebrate species of Mexico (SEMARNAT 2010, www.iucnredlist.org). This means that: resulting prioritization scenarios should be considered only for large vertebrate conservation. In addition, complementary criteria in the selection of this species assemblage were the date and number of available records and the state of the ecological knowledge about the species. All species of this assemblage must share the following ecological attributes: low reproduction rate, low population size, specific needs for mating behavior, habitat specialization, mid-to-large home range and long lifespan.

All distribution records from the set of large vertebrate species of Mexico were gathered, filtered and compiled into a single database. Records were gathered from the 
following sources: CONABIO (www.conabio.gob.mx), GBIF (www.gbif.org), MANIS (www.manisnet.org) and the scientific literature. Filtering included the following criteria: only records from 1901 until 2012; exclusion of clearly incorrect geographic distribution locations, records from unsuitable ecological locations and duplicate records from the same year, from the same source, at the same site (only one record per $1 \mathrm{~km}^{2}$ was included). The compiled database was then randomly split into two groups. The first group comprised $70 \%$ of the records and was used to develop ecological niche models, whereas the second group contained $30 \%$ of the records and was used to validate the outcomes.

The following environmental and anthropogenic attributes were used to develop ecological niche models: land cover, human population density, elevation, slope, and bioclimatic surfaces. The land cover database came from the National Institute of Statistics and Geography, series V; original scale 1:250,000 (INEGI, 2005). Based on Pérez-Vega et al. (2008), the original 77 cartographic categories of INEGI land cover types were combined into 10 categories in order to relate them to land cover types (water bodies and anthropogenic attributes were not considered; see file Table S1 at: http:/www.ciga.unam.mx/ velazquez/HCM/). We used population density as a proxy for anthropogenic disturbance as described by Salvatore et al. (2005). Elevation was available through the USGS/NASA Shuttle Radar Topography Mission (USGS 2007), and was used to calculate slope. The 19 bioclimatic surfaces were obtained from Téllez et al. (2011). These attributes were spatially rescaled to fit within a pixel size of $10 \mathrm{~km}^{2}$. Collinearity among attributes was tested using Pearson coefficients (Hirzel et al. 2002). When two or more attributes were highly correlated $(\mathrm{R}>0.5)$, only one was retained as independent attribute and the other(s) eliminated.

Five niche modeling approaches were used to provide geographical context for the set of large vertebrate species of Mexico (Franklin 2009), namely, BIOCLIM (Busby 1991), Euclidian distance (Carpenter et al. 1993), Mahalanobis distance (Corsi et al. 1999), MaxEnt (Phillips et al. 2006; Phillips and Dudik 2008) and Genetic Algorithm for Rule Set Production (GARP, Stockwell and Noble 1992). The first three are based on distance method algorithms, whereas the last two are artificial intelligence-based algorithms (Rangel and Loyola 2012). Ten repetitions were applied for each approach with the aid of the BioEnsembles platform (Diniz-Filho et al. 2009; Rangel et al. 2009). To assess the performance of the approaches, the area under the ROC curve (AUC) was calculated as suggested by Swets (1995). Two ensemble models were generated for each species, one with the average output from the three distance models (distance ensemble model [here after referred as DEM] generated with BIOCLIM, Euclidean Distance and Mahalanobis distance) and the other with the average output from artificial intelligence models (artificial intelligence ensemble model [here after referred as AIEM] generated with MaxEnt and GARP; Roura-Pascual et al. 2008). The ensemble method(s) (in each case DEM separately from AIEM?) used a weighted average, based on the values of the AUC (Marmion et al. 2009).

\section{Species weighted value}

An added weighted value based upon risk of extinction, rarity and body size was assigned to all species as suggested by Loyola et al. (2008). Risk of extinction was extracted from SEMARNAT (2010) and from the IUCN Red List (2012). Categories from both sources were converted into a constant index as suggested by Purvis et al. (2000): insufficient data and least concern $=0$; near threatened $=1$; endangered $=2$; critically endangered $=3$. Rarity was assigned to all species following Gaston (2002), according to the following 
algorithm in which geographic range refers to the historical distribution area as reported by IUCN (2012).

$$
\mathrm{R}=1 / \text { geographic range in } \mathrm{km}
$$

Species body size was obtained from Smith et al. (2004), Sunquist and Sunquist (2002), Ferguson- Lees et al. (2001) and Hoyo et al. (2005). The mean value in grams was transformed into logarithmic values. The weighted values for each of risk of extinction, rarity and body size were normalized to fit into a gradient from zero (lowest value) to one (highest value). The added weighted value of a given species was obtained by summing the independent values of risk of extinction, rarity and body size, so that an added weighted value of 3 (maximum) for a given species would imply the prime importance of a species.

\section{Triggering conservation attributes}

We obtained five attributes that can affect the implementation of biodiversity conservation efforts in Mexico, namely, local governance (LG), land acquisition value (LAV), human agglomeration (HA), anthropogenic land use (ALU) and land cover persistence (LCP) (see Figure $\mathrm{S} 1$ at http://www.ciga.unam.mx/velazquez/HCM/).

Local governance (LG) is here referred to as the potential willingness of local communal or indigenous groups to launch conservation efforts. According to Velázquez et al. (2010) and Skutsch et al. (2013), around 43\% (82,710,638 ha) of the total surface area of Mexico consists of native forested ecosystems, of which 48,637,820 ha are under the legal jurisdiction of 20,142 rural agrarian communities. Bray et al. (2007), Lopez-Feldman et al. (2011) and Duran-Zuazo et al. (2013) demonstrated that Mexican agrarian communities larger than 3000 ha with over $50 \%$ of surface area comprised of native forested ecosystems have the potential to conduct sustainable management by themselves based upon strong traditional community governments. We produced a map depicting agrarian communities sharing these characteristics. Complementary areas successfully reforested through the initiative of these local governments (SIMBAD-INEGI 2010, http://sc.inegi.org.mx/ sistemas/cobdem/) were added to this map to obtain a full cartographic expression of the LG attribute.

Land acquisition value (LAV) was meant to capture areas that are affordable to purchase for conservation purposes. This is important, since conservation on communal or private lands should be based on land use acquisition rather than government expropriation, which could lead to illegal extraction activities on the expropriated land. LAV was inferred from gross annual income per capita (INEGI 2011, http://sc.inegi.org.mx/sistemas/ cobdem/). The most affordable lands were those found in municipalities with the lowest gross annual income per capita. LAV was calculated by transforming polygon data from municipalities into raster format at pixel level $\left(1 \mathrm{~km}^{2}\right.$ resolution).

Human agglomeration (HA) included delineating areas where more conflicts on conservation issues would likely occur as human density increases. The source was the FAO database in raster format (Salvatore et al. 2005) with a pixel resolution of $1 \mathrm{~km}^{2}$.

Anthropogenic land use (ALU) was meant to distinguish areas where current productive activities such as agriculture and livestock production would likely lead to resistance of conservation efforts. The source to depict agriculture came from INEGI (Series III, scale 1:250,000; year 2005). This layer was overlaid in raster format on the database of livestock density from FAO (2007). A pixel value was assigned as: pixels comprising agriculture and livestock production $=2$; one of the two land uses $=1$; and none of the land uses $=0$. 
Land cover persistence (LCP) was obtained by projecting land cover types based on land cover change analysis from two sources, namely, INEGI series I (1976) and National Forest Inventory 2000 (SEMARNAT 2001). These two databases were made compatible and comparable and were overlaid to depict changes, following Velázquez et al. (2002) and Mas et al. (2004). The land cover changes were overlaid on a road distribution map (http:// conabioweb.conabio.gob.mx/metacarto/metadatos.pl.) and on the digital elevation model produced by using the "land change modeller module" in Eastman and IDRISI (2012). From these overlays, land cover persistence was expressed in a Markov chain system and projected until 2024.

These triggering conservation attributes were subsequently stretched to enhance interpretation with the aid of Eastman and IDRISI (2012).

\section{Scenario construction}

We used Zonation software (Version 3.1.1, Moilanen et al. 2011) to develop two different prioritization scenarios through trade-off analysis. The first scenario considered only the ecological niche models of each species and the species weight value (we called this the "biological scenario"). The second considered the output of the first scenario plus the six trigging conservation attributes previously described (we called this the "integral scenario"). These scenarios were developed for the two kinds of ensemble models derived from the distance and artificial intelligence algorithms.

The triggering conservation attributes were considered either beneficial or constraints for conservation purposes. Local governance (LG) and land cover persistence (LCP) were beneficial, whereas land acquisition value (LAV), human agglomeration (HA) and anthropogenic land use (ALU) were regarded as constraints. Following Moilanen et al. (2011), beneficial attributes were assigned a value of 1 , while constraints were assigned a value of -0.5 , so that bias was prevented as much as possible.

Scenarios were smoothed for each species using the smoothing function in the Zonation software, so that isolated scattered pixels are regarded as less relevant than scattered neighboring pixels of polygons, in order to avoid the so-called "salt and paper effect." The amplitude of the smoothing process was based on dispersion capacity, estimated from the home range of the species. These values per species were obtained from the available literature (Madrid et al. 1991; Snyder 1993; Don-Crider 1995; De Oliveira 1998; Sunquist and Sunquist 2002; Scognamillo et al. 2003; Ariano-Sánchez 2006; Carvajal et al. 2007; Dillon and Kelly 2008; Muñiz-Lopéz 2008; CONABIO 2011). Core areas were delineated and displayed in black, whereas buffer areas were shown in light grey. Core areas were regarded as territory with more opportunity to enhance large vertebrate conservation in Mexico.

"Territories of opportunity" were delineated by identifying legitimate agrarian communities ("ejidos" and indigenous communities, sensu Velázquez 2012) within the core areas. Agrarian community boundaries were obtained from the Registro Agrário Nacional (http://fanar.ran.gob.mx/cgi-bin/nucleos1?). We finally compared the obtained territories of opportunity with the current protected areas. Polygons of protected areas were downloaded from CONABIO (http://www.conabio.gob.mx/ informacion/gis/). Maps were overlaid in ArcGIS (Version 10.1). 


\section{Results}

\section{Ecological niche models}

Twenty vertebrates fulfilled the ecological criteria to form the set of large vertebrate species of Mexico (Table 1). This assemblage includes four reptiles, nine birds and seven mammals in 16 genera and seven families. Out of 3235 species records, 2123 fulfilled quality criteria to provide reliable species distribution patterns. Records were unevenly distributed among species, so that the species with most records was the Jaguar (Panthera onca) with 510, whereas the Harpy Eagle (Harpia harpyja) had the least number of records (12).

The added weighted value pinpointed five species as outstanding conservation targets, namely, the Black Bear (Ursus americanus), the American Crocodile (Crocodylus acutus), the Harpy Eagle (Harpia harpyja), the Jaguar (Panthera onca) and the Solitary Eagle (Harpyhaliaetus solitarius). Seven other species had values above 1.7, whereas only one (Lynx rufus) had a significantly low value (Table 1).

From the 30 environmental attributes originally included into the analysis, only 15 were selected for generating ecological niche models. Originally, over 80 correlation values higher than 0.50 (positive or negative) were obtained among the 30 attributes (see Table S2 at http://www.ciga.unam.mx/velazquez/HCM/). Statistically, this suggests high probability of covariance; by selecting 15 attributes, statistical noise was reduced and modeling certainty was improved. Nonetheless, there remained a few (seven) correlation values higher than 0.50 (positive or negative) among the selected 15 attributes (see Table S3 at: http://www.ciga.unam.mx/velazquez/HCM/). Elevation and mean annual temperature, in particular, were significantly correlated $(\mathrm{R}=-0.88)$. These 15 attributes, here referred to as "explanatory," have been used by other authors in niche modeling in spite of their high correlation. Implications of this are discussed further, below.

The values obtained from species niche modeling for each algorithm differed slightly. On the whole, values from artificial intelligence algorithms (mean AUC value of the two methods used $=0.87$ ) were substantially higher that those obtained by distance methods algorithms (mean AUC value of the three methods used =0.76). The ensemble model, however, was equally effective for both types of algorithms (mean AUC $=0.91$ ). The ensemble model, as expressed by the mean AUC value of all algorithms, varied for each species (Table 2). Equal mean AUCs ensemble values do not imply similar distribution patterns. Regardless the algorithm used, prediction of species' distributions patterns showed that seven of the 20 species occurred predominantly in Neotropical conditions (Cathartes burrovianus, Crocodylus acutus, Harpia harpyja, Leopardus wiedii, Sarcoramphus papa and Spizaetus tyrannus). Eight species extended their Neotropical ranges along the coasts towards areas with northern conditions (Boa constrictor, Harpyhaliaetus solitarius, Heloderma horridum, Leopardus pardalis, Panthera onca, Puma yagouaroundi, Spizaetus ornatus and Spizastur melanoleucus). The remaining five species (Aquila chrysaetos, Haliaeetus leucocephalus, Lynx rufus, Puma concolor and Ursus americanus) predicted distribution was mainly restricted to Nearctic conditions. A comprehensive spatial distribution pattern of all ecological niches predicted for each of the 20 species can be seen in Figures S2 and S3 at: http://www.ciga.unam.mx/velazquez/ $\mathrm{HCM} /$. 


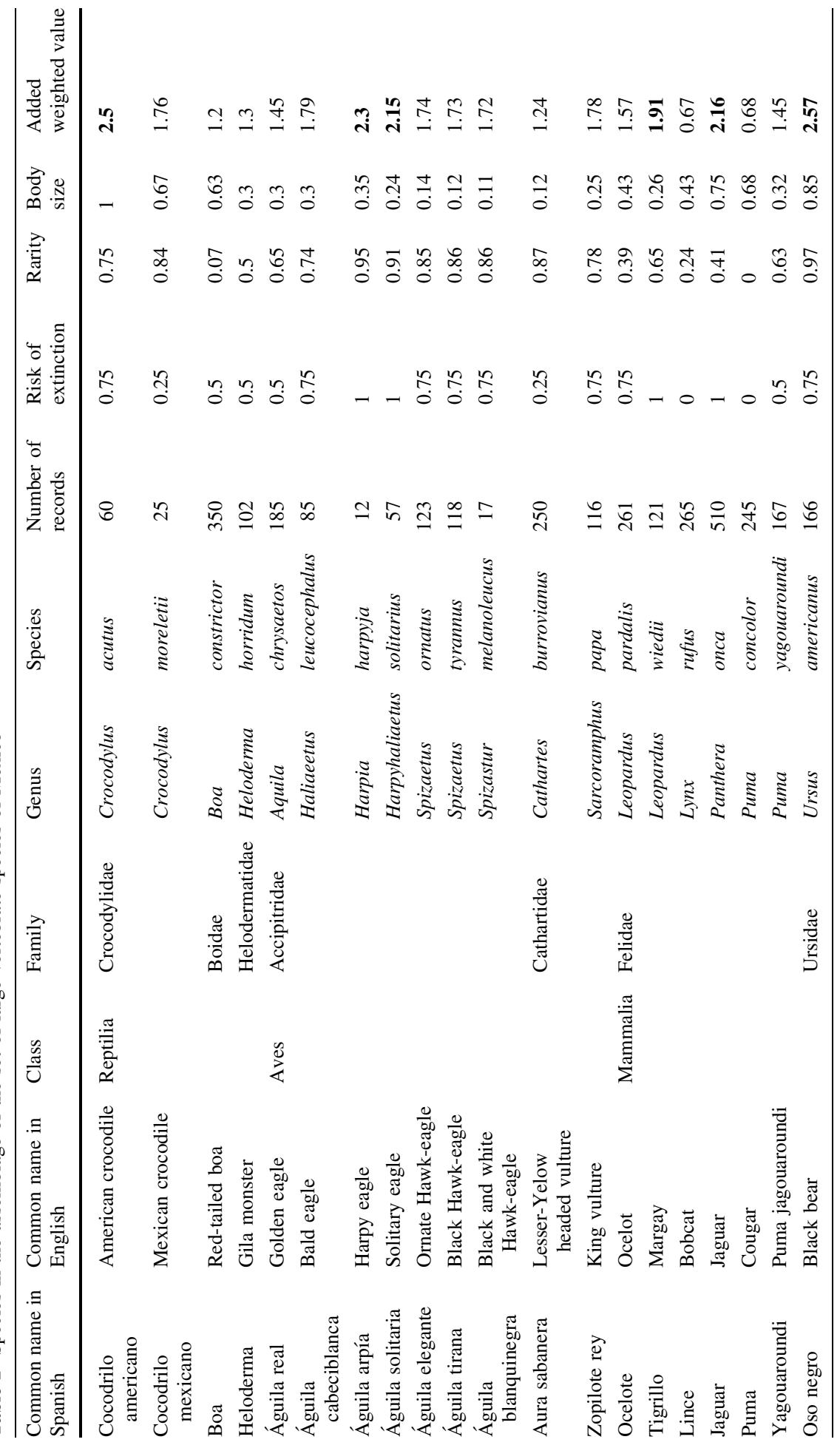


Table 2 Area under the curve (AUC) obtained for species in the assemblage of the set of large vertebrate species of Mexico

\begin{tabular}{|c|c|c|c|c|c|c|c|}
\hline \multirow[t]{3}{*}{ Specie } & \multicolumn{7}{|c|}{ Type of algorithm; specific algorithm used } \\
\hline & \multicolumn{4}{|l|}{ Distance } & \multicolumn{3}{|c|}{ Artificial intelligence } \\
\hline & BioClim & $\begin{array}{l}\text { Ecuclidean } \\
\text { Distance }\end{array}$ & $\begin{array}{l}\text { Mahalanobis } \\
\text { Distance }\end{array}$ & Ensemble $^{\mathrm{a}}$ & GARP & MaxEnt & Ensemble \\
\hline $\begin{array}{l}\text { Crocodylus } \\
\text { acutus }\end{array}$ & 0.97 & 0.85 & 0.95 & 0.86 & 0.95 & 0.98 & 0.88 \\
\hline $\begin{array}{c}\text { Crocodylus } \\
\text { moreletii }\end{array}$ & 0.98 & 0.79 & 0.71 & 0.76 & 0.91 & 0.97 & 0.84 \\
\hline Boa constrictor & 0.81 & 0.77 & 0.83 & 0.98 & 0.82 & 0.91 & 0.9 \\
\hline $\begin{array}{r}\text { Heloderma } \\
\text { horridum }\end{array}$ & 0.76 & 0.54 & 0.66 & 0.9 & 0.74 & 0.9 & 0.98 \\
\hline $\begin{array}{l}\text { Aquila } \\
\quad \text { chrysaetos }\end{array}$ & 0.65 & 0.53 & 0.61 & 0.95 & 0.67 & 0.88 & 0.94 \\
\hline $\begin{array}{l}\text { Haliaeetus } \\
\quad \text { leucocephalus }\end{array}$ & 0.95 & 0.92 & 0.9 & 0.96 & 0.88 & 0.95 & 0.73 \\
\hline Harpia harpyja & 0.99 & 0.5 & 0.81 & 0.8 & 0.93 & 0.93 & 0.94 \\
\hline $\begin{array}{l}\text { Harpyhaliaetus } \\
\text { solitarius }\end{array}$ & 0.74 & 0.52 & 0.69 & 0.93 & 0.82 & 0.86 & 0.9 \\
\hline $\begin{array}{r}\text { Spizaetus } \\
\text { ornatus }\end{array}$ & 0.89 & 0.5 & 0.84 & 0.96 & 0.83 & 0.92 & 0.96 \\
\hline $\begin{array}{l}\text { Spizaetus } \\
\text { tyrannus }\end{array}$ & 0.91 & 0.69 & 0.91 & 0.96 & 0.91 & 0.96 & 0.95 \\
\hline $\begin{array}{l}\text { Spizastur } \\
\quad \text { melanoleucus }\end{array}$ & 0.96 & 0.5 & 0.77 & 0.8 & 0.91 & 0.88 & 0.97 \\
\hline $\begin{array}{l}\text { Cathartes } \\
\text { burrovianus }\end{array}$ & 0.93 & 0.68 & 0.94 & 0.93 & 0.94 & 0.97 & 0.78 \\
\hline $\begin{array}{l}\text { Sarcoramphus } \\
\quad \text { papa }\end{array}$ & 0.93 & 0.76 & 0.91 & 0.92 & 0.91 & 0.94 & 0.94 \\
\hline $\begin{array}{l}\text { Leopardus } \\
\text { pardalis }\end{array}$ & 0.79 & 0.65 & 0.77 & 0.97 & 0.78 & 0.89 & 0.92 \\
\hline $\begin{array}{l}\text { Leopardus } \\
\text { wiedii }\end{array}$ & 0.86 & 0.71 & 0.87 & 0.98 & 0.84 & 0.9 & 0.91 \\
\hline Lynx rufus & 0.65 & 0.57 & 0.61 & 0.97 & 0.74 & 0.84 & 0.97 \\
\hline Panthera onca & 0.77 & 0.54 & 0.77 & 0.98 & 0.77 & 0.83 & 0.92 \\
\hline Puma concolor & 0.61 & 0.5 & 0.52 & 0.9 & 0.67 & 0.81 & 0.9 \\
\hline $\begin{array}{l}\text { Puma } \\
\qquad \text { yagouaroundi }\end{array}$ & 0.81 & 0.54 & 0.82 & 0.82 & 0.81 & 0.93 & 0.92 \\
\hline $\begin{array}{l}\text { Ursus } \\
\quad \text { americanus }\end{array}$ & 0.85 & 0.76 & 0.78 & 0.97 & 0.81 & 0.93 & 0.97 \\
\hline Min & 0.61 & 0.5 & 0.52 & 0.76 & 0.67 & 0.81 & 0.73 \\
\hline Max & 0.99 & 0.92 & 0.95 & 0.98 & 0.95 & 0.98 & 0.98 \\
\hline Mean & 0.84 & 0.65 & 0.78 & 0.91 & 0.83 & 0.91 & 0.91 \\
\hline
\end{tabular}

\footnotetext{
${ }^{\text {a }}$ Ensemble of algorithm methods; see text for calculation of ensemble
} 


\section{Triggering conservation attributes}

LG, as defined in Methods, covered an area of 16 million ha, $7.9 \%$ of the surface area of Mexico. Native land cover, as a surrogate for natural ecosystems, still covers 83 million ha, $43 \%$ of the surface area of Mexico. LCP indicated that the most resilient ecosystems, expressed by the annual rate of change, were hydro vegetation series $(x=0.32)$ followed closely by scrubland $(\mathrm{x}=0.40)$. In contrasts, tropical forests $(\mathrm{x}=1.95)$ and natural grassland $(\mathrm{r}=1.55)$ experienced the most dramatic losses (see further details of land cover change in Sánchez-Colón et al., 2009). HA showed a rather compact pattern, in which $56.82 \%$ of the present Mexican population is found in only $8.74 \%$ of the country (see SEDESOL et al. 2010). Human settlements, however, demand resources from distant places, and among these resources, ALU are found in about $28.8 \%$ of the country; in these areas, the opportunity for species conservation is less favorable. In addition, areas where ALU and HA overlapped also coincided with elevated cost of the land (LAV), allowing us to distinguish between areas suitable for land use and for conservation (see Figure S4 at http://www.ciga.unam.mx/velazquez/HCM/). Hence, HA, ALU and LAV were regarded as negative triggering conservation attributes. In short, LCP coupled with areas with LG identified regions where conservation is most likely to occur. In contrast, regions where HA, ALU and LAV overlapped were regarded as unsuitable areas from a conservation viewpoint.

\section{Relationship between biological and integral scenarios}

The distribution pattern of the set of large vertebrate species of Mexico (biological scenario), resulting from the artificial intelligence and distance algorithms, were displayed (Fig. 1a, b) and compared. The comparison showed that outputs differed slightly. Buffer zones from the two types of algorithms overlapped $56.97 \%$, whereas core areas overlapped only $31.71 \%$. Actual net discrepancies between artificial intelligence and distance methods outputs amounted to $7.4 \%$ of the surface area of Mexico (14.6 million ha).

We compared, geographically, the overlap of all triggering conservation attributes and showed that the largest concentration of the set of large vertebrate species under the biological scenario converges on regions with high LCP and LG. Conversely, regions with high human population and agricultural and livestock production activities, in addition to expensive land acquisition, are also areas where the assemblage of the set of large vertebrate species of Mexico is limited.

In the integral scenarios, slight differences were found between artificial intelligence and distance methods algorithms (Fig. 2a, b). In the integral scenarios, buffer zones overlapped $60.08 \%$, whereas core areas overlapped $40.24 \%$. Actual net discrepancies between artificial intelligence and distance methods outputs amounted to $8.99 \%$ of the surface area of Mexico (17.6 million ha) (Fig. 2a, b). However, both methods coincided to pinpoint the most relevant areas: the eastern slopes of the Sierra Madre Occidental, chiefly in Chihuahua state; the Pacific coast including large portions of Oaxaca and Chiapas states; and the southern region of the Gulf of Mexico, including the Yucatan Peninsula, and parts of the Petén basin in Campeche state and the Soconusco region in Chiapas state. Conversely, the greatest differences between outputs of the two methods were found in the Mexican Plateau, mainly restricted to Coahuila and San Luis states. It is worthwhile mentioning that some already known regions of high importance for its ecosystem 


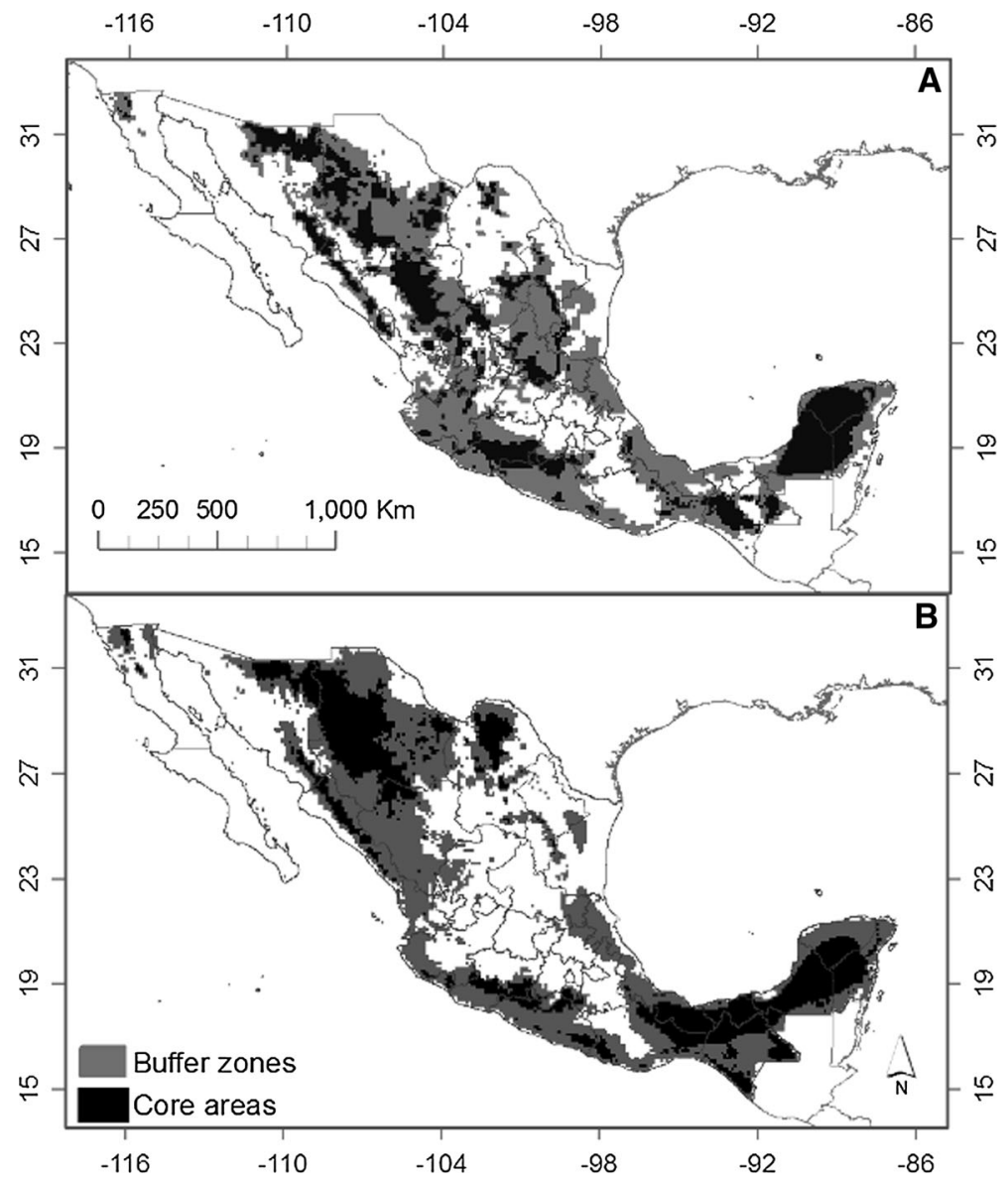

Fig. 1 Map of the outputs obtained from the assemblage of the set of large vertebrate species of Mexico. a Areas identified by performing three distance method algorithms (BIOCLIM, Euclidian distance and Mahalanobis distance). b Areas identified by performing two artificial intelligence algorithms (MaxEnt and GARP)

diversity were not depicted by these set of species. This is the case of upper hills of the Western and East Sierra Madre ranges and The Sonoran desert to mention a few.

The overlap between the outputs from the artificial intelligence and distance methods (Fig. 3a, b) was more specific in identifying hot spots (Fig. 3b). This joint map showed that areas predicted by artificial intelligence and distance methods overlapped in $9.56 \%$ of the country (18.8 million ha). In addition to the joint areas, artificial intelligence methods predicted areas of 14.3 million ha (amounting to $7.3 \%$ of the surface area of Mexico), whereas distance algorithms predicted areas of 14.6 million ha (7.4\% of the country) outside the overlapping areas. Hence, the total of area predicted by both types of methods covered $24.3 \%$ of the surface area of Mexico (47.9 million ha). Four continuous regions turned out to be remarkably relevant: north of Mexican Plateau (mainly within Chihuahua state), western slopes of the Sierra Madre Occidental; northern region of the Sierra Madre Oriental, and most of the Yucatan Peninsula. One additional scattered area is outstanding: the Pacific coast from Jalisco southwards, including large parts of Oaxaca and Chiapas 


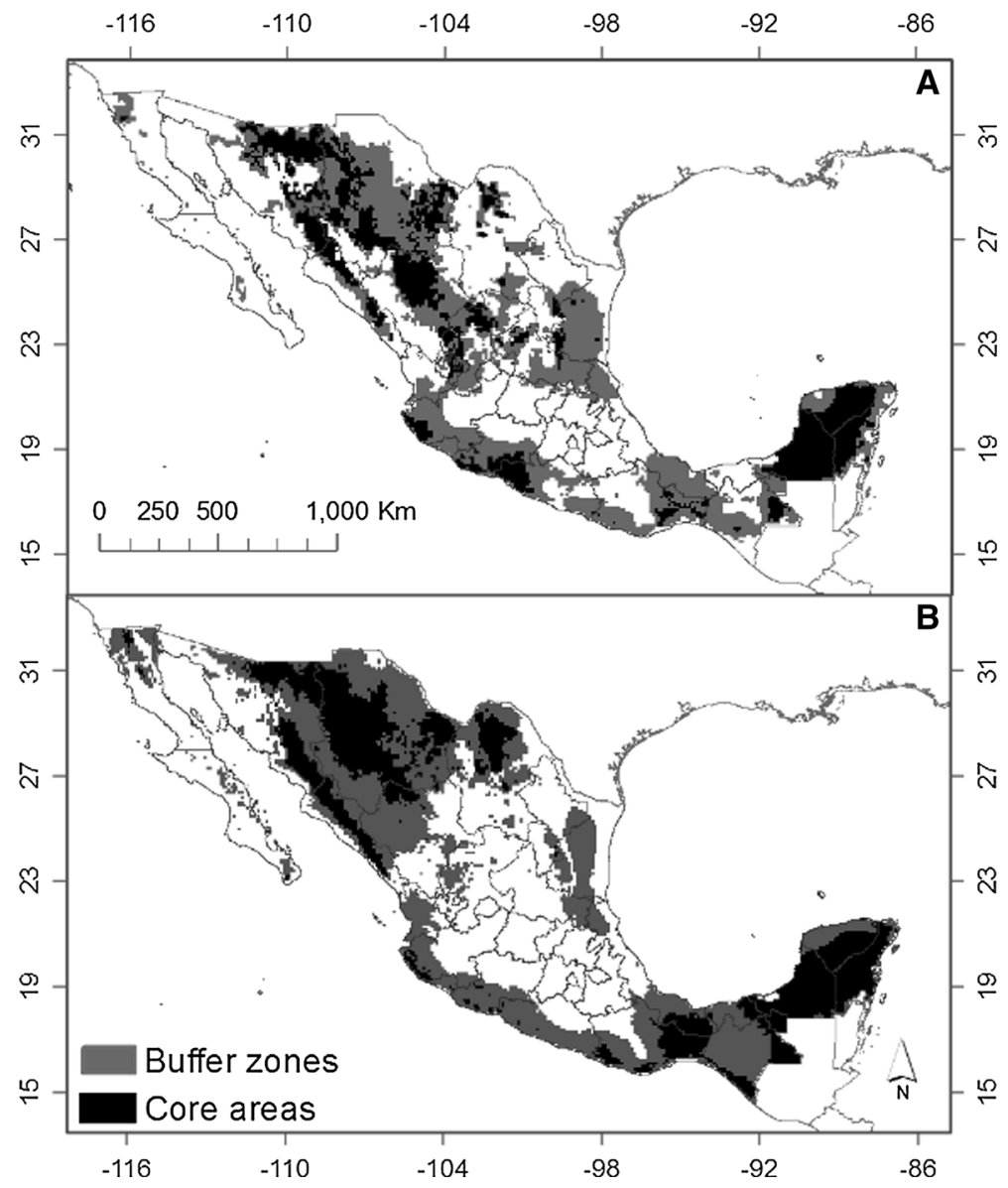

Fig. 2 Map of the outputs obtained from the assemblage of the set of large vertebrate species of Mexico and the five triggering anthropogenic attributes. a Areas identified by performing three distance method algorithms (BIOCLIM, Euclidian distance and Mahalanobis distance). b Areas depicted by performing two artificial intelligence algorithms (MaxEnt and GARP)

states. It is worthwhile mentioning that biological scenarios derived from the two types of algorithms depicted other relevant areas, such as the Balsas Depression and portions of the Transversal Neovolcanic Axis, where HA, ALU and LAV anthropogenic attributes exclude them as potential targets for short-term conservation.

Based on these results, the most realistic conservation scenarios are those involving by agrarian communities capable of implementing conservation actions. Capability to implement conservation was here deduced from the level of organization and the amount of natural resources managed sustainably. A critical selection of these agrarian communities was made within the $24.3 \%$ of the country predicted as suitable for conservation by the two methods. According to Fig. 3b, $12 \%$ of the country (23.5 million ha) currently under the jurisdiction and management of agrarian communities, would be sufficient to ensure the survival of the assemblage of the set of large vertebrate species of Mexico. By comparing, geographically, these particular results with the present area under the jurisdiction of the National Commission of Protected Areas in Mexico (CONANP, from its 


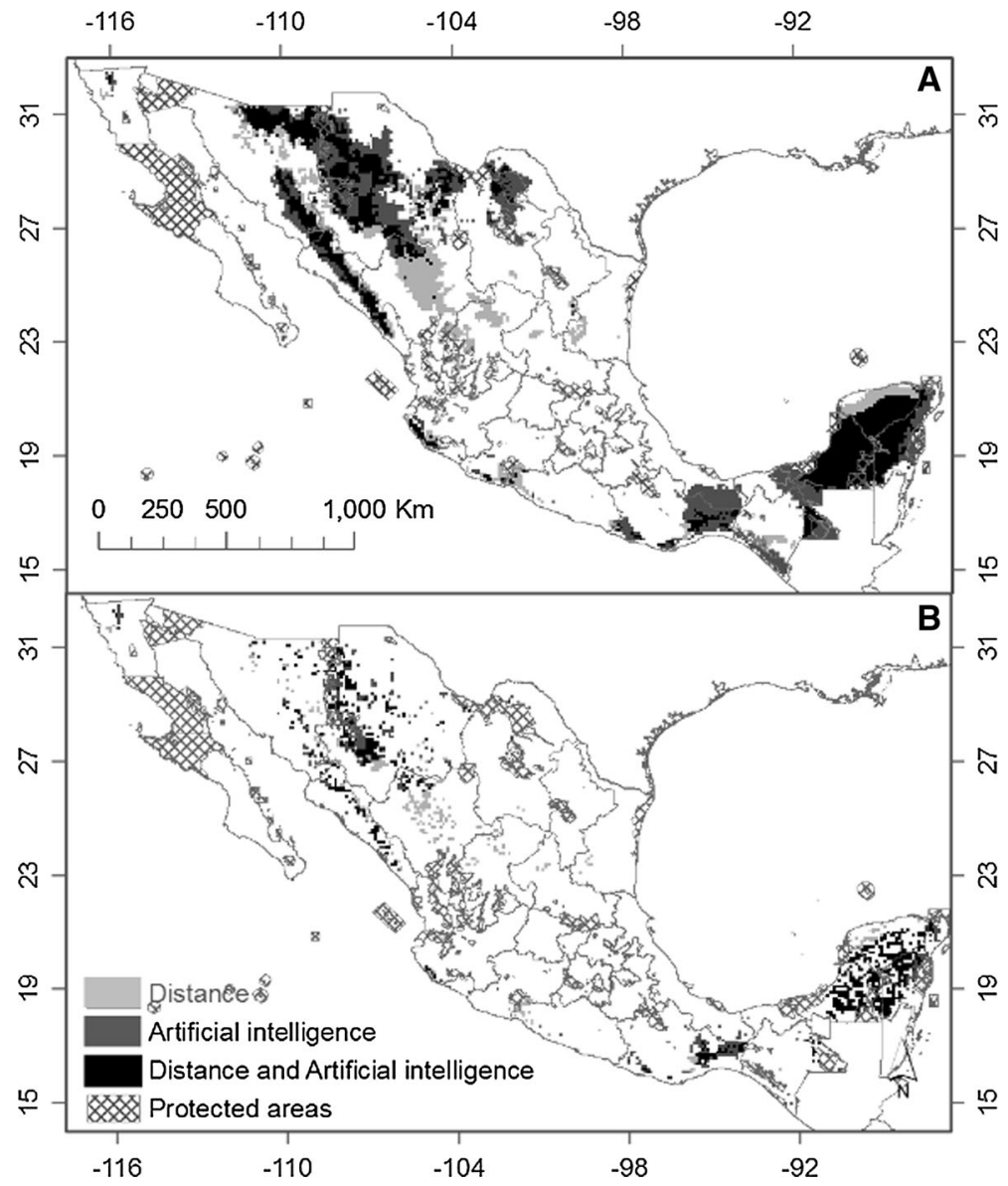

Fig. 3 Map of the outputs obtained from the assemblage of the set of large vertebrate species of Mexico and the five triggering anthropogenic attributes, showing overlapping and unique areas from various models. b Areas identified by performing three distance methods algorithms (BIOCLIM, Euclidian distance and Mahalanobis distance), by performing two artificial intelligence algorithms (MaxEnt and GARP), and overlap between these areas. b Areas as in A where agrarian communities were selected as likely allies because of their governance structures. In $\mathbf{a}, \mathbf{b}$ established protected areas are denoted by the hatched pattern

acronym in Spanish), we find that only 2.7\% (54.1 million ha) of the area predicted overlaps with CONANP-protected areas (Fig. 3b). Thus, the conservation policies currently established are not targeted towards ensuring the survival of the set of large vertebrate species by means of engagement of local stakeholders.

\section{Discussion}

The present paper departs from the concept of territory: an orderly, humanized place where nature and culture are treated as inseparable by clearly defined social institutions in charge of creating and implementing rules targeted at pursuing stakeholders' actions (Raffestin and Butler 2012). Delineation of territories to enhance biodiversity conservation has been 
largely neglected, since most academic efforts for species conservation consider only the relationship between species and environmental attributes (Fahrig 2001; Pressey and Bottrill 2008; Kearney and Porter 2009; Moilanen et al. 2009; Peterson and Nakazawa 2008). From the results presented here, we joint ecological, geographical and cultural attributes to identify territories of opportunity for large vertebrates' conservation in Mexico. Local stake(space)holders, such as agrarian communities ("ejidos" in the Mexican context), do not hold government platforms evenly powerful so that certain criteria must be fulfilled to consider an agrarian community as likely conservation allies. Similarly, species need to be selected as priority targets for conservation, based on a number of criteria (www.iucnredlist.org/). Few academic efforts have been made to assess local stakeholders' governance systems for conservation purposes, and criteria may differ drastically from one place to another (Ostrom 2010; Lopez-Feldman et al. 2011; Eklund et al. 2011). The strength of our approach lies in the simultaneous analysis of ecological, geographical and cultural criteria in order to identify territories of opportunity for conservation.

By contrast, criteria for ranking species for conservation are clearly established and applied to all species worldwide (Myers et al. 2000). It is yet to be ascertained whether the present outputs applied to set conservation priorities to all Mexican large vertebrate species. Ongoing research and previous studies provide coincidences pointing towards valid conclusions for birds (Escalante-Pliego et al. 1993; Peterson and Nakazawa 2008), endemic terrestrial mammals Escalante et al. 2007), and species richness analyses by ecoregion (Urquiza-Haas et al. 2011a, b). Nonetheless, meanwhile more comprehensive studies are conducted, the present results may guide conservation priorities for large vertebrates, regarding than time, financial and human resources are limited.

The present research, in order to be considered holistic, must be enriched by including other endangered, endemic, rare, poorly know species such as plants and insects (Simberloff 1998; Bonn et al. 2002; Bode et al. 2008). In this sense, emerging methodological data analysis to help shrinking present limitations to set conservation priorities are the uppermost priority. Taking into account that jointly including ecological, geographical and cultural data analyses are scanty; this contribution may serve to shorten current limitations.

From the pure statistical view, a number of the species included here do not fulfill criteria to apply sound niche modeling (Table 2). Marmion et al. (2009) for instance, recommend that species with AUC values lower than 0.5 (e.g., Harpia harpyja, Harpyhaliaetus solitarius and Spizaetus ornatus) may not provide enough certainty for niche modeling. However, AUC values change drastically between algorithms; hence, we computed five different niche models. The output obtained by the ensemble model of the three distances methods-based approaches and the ensemble model of the two artificial intelligence-based approaches proved identical; statistical power was comparable (Table 2) and statistical differences were negligible. In addition, niche modeling is strongly based upon environmental attributes that are strongly correlated (Busby 1991; Franklin 2009). It is widely held that covariance enhances error propagation, thus affecting uncertainty in the final output. Research to date shows that environmental attributes such as climatic and geographical features influence species distribution patterns as a whole. Niche modeling, however, splits climatic and geographical features into layers in order to consider the role of the different components of these features (Peterson and Nakazawa 2008; Franklin 2009; Diniz-Filho et al. 2009; Téllez et al. 2011). Consequently, covariance among layers is likely and must be taken into account to diminish error propagation (Hirzel and Gwenaëlle 2008). In short, uncertainty in niche modeling resulting from statistical and data 
quality and availability remains an issue. However, our results document the methods to proceed with enhancing species conservation, in spite of incomplete ecological and geographical knowledge about the set of large vertebrate species. This approach thus addresses the theoretical component of niche modelling and the practical component of conservation actions.

There are a number of implications for the Mexican context. First, Mexico's network of protected areas has increased significantly in surface area (over 25 million ha) and number of areas (176) established within a century of time (www.conanp.gob.mx). As is the case for most conservation efforts in similar developing countries, the intention to protect these areas collapses because of a lack of enforcement; evidence shows that effective conservation within protected areas is limited (Brechin et al. 2003; Figueroa and Sánchez-Cordero 2008). The role of Mexican agrarian communities in effective biodiversity conservation have been highlighted repeatedly (Velázquez et al. 2001, 2003; Ellis and Porter-Bolland 2008). However, despite the evidence, this paper demonstrates that the current Mexican network of protected areas has largely neglected territories of opportunity where local allies and the set of large vertebrate species coexist. Second, a large number of efforts have aimed to delineate the most likely areas for enhancing Mexican biodiversity conservation (Ceballos et al. 2009; Mittermeier et al. 1999; OrtegaHuerta and Peterson 2004; Illoldi-Rangel et al. 2008; Navarro-Sigüenza et al. 2011; Ochoa-Ochoa et al. 2011; Urquiza-Haas et al. 2011a, b; Koleff et al. 2011; Tobón et al. 2012). Naughton-Treves et al. (2005b), for instance, conducted a thorough analysis to identify areas where biodiversity could be conserved with minimal social conflict; they identified "socially empty" areas, since local stakeholders were regarded as the main threat to maintaining biodiversity. The present paper proves that a number of agrarian communities have coexisted for millennia with outstanding biodiversity assemblages; identifying these communities can help us gain allies in biodiversity conservation. This conceptual framework of local stake(space)holders as allies is consistent with other contributions related to forest conservation (Bray and Merino-Perez 2003), watershedforest management (Duran-Zuazo et al. 2013), and carbon sequestration (Klooster and Masera 2000). Long-term sound management conducted by local agrarian communities also seems promising to ameliorate current global change effects (Skutsch et al. 2013), since biodiversity is unequivocally a good indicator of ecosystem integrity (Sarukhán et al. 2015). However, the effective role of these territories of opportunity in climate change is yet to be ascertained.

To conclude, countries harbouring large biodiversity stocks should strengthen local stake(space)holders, turning potential threats into conservation allies (Bray and Velázquez 2009). These likely allies govern territories that hold large potential for climate change mitigation. The global extent of the role of agrarian communities in enhancing sound management of natural capital has yet to be ascertained. However, our results suggest that policy-makers need to be engaged to harness potential willingness to act for environmental conservation (sensu Faleiro and Loyola 2013). Emerging innovative conceptual frameworks also need to be incorporated in the sound management of natural capital (Knight et al. 2009; Sarukhán et al. 2015). In spite of the uncertainty due to lack of data availability and statistical limitations of tools, engagement of well-governed agrarian communities may play a key role in ameliorating current environmental deterioration worldwide. 


\section{References}

Ariano-Sánchez D (2006) The Guatemalan beaded lizard: endangered inhabitant of a unique ecosystem. Iguana 13:179-183

Ávila-Blomberg A (2008) La diversidad lingüística y el conocimiento etnobiológico. In: Sarukhán J (ed) El Capital Natural de México. CONABIO, Mexico, pp 497-556

Balmford A (2002) Selecting sites for conservation. In: Norris K, Pain DL (eds) Conservation bird biodiversity: general principles and their application. Cambridge University Press, Cambridge, pp 74-104

Balvanera P, Pfisterer AB, Buchmann N, He J, Nakashizuka T, Raffaelli D, Schmid B (2006) Quantifying the evidence for biodiversity effects on ecosystem functioning and services. Ecol Lett 9:1146-1156

Berkes F, Folke C (1998) Linking social and ecological systems for resilience and sustainability. In: Berkes F, Folke C (eds) Linking social and ecological systems: management practices and social mechanisms for building resilience, vol 1, pp 13-20

Berkes F, Coldinng J, Folke C (2000) Rediscovery of traditional ecological knowledge as adaptive management. Ecol Appl 10(5):1262-1551

Bode M et al (2008) Cost-effective global conservation spending is robust to taxonomic group. Proc Natl Acad Sci USA 105:6498-6501

Bonn A, Rodrigues ASL, Gaston KJ (2002) Threatened and endemic species: ¿are they good indicators of patterns of biodiversity on a national scale? Ecol Lett 5:733-741

Bray DB, Merino-Perez L (2003) El Balcón, Guerrero: a case study of globalization benefiting a forest community. In: Wise TA, Salazar H, Carlsen L (eds) Confronting globalization: Economic integration and popular resistance in Mexico. Kumarian Press, Bloomfield, pp 65-80

Bray DB, Velázquez A (2009) From displacement-based conservation to placebased conservation. Conserv Soc 7:11-14

Bray DB, Merino-Pérez L, Barry D eds (2007) Los Bosques Comunitarios de México. Manejo Sustentable de Paisajes Forestales. INE-SEMARNAT, Consejo Civil Mexicano para la Silvicultura Sostenible, Instituto de Geografía UNAM, Florida International University. México, pp 443

Bray DB, Duran E, Ramos VH, Mas JF, Velázquez A, McNab BRB, Barry D, Radachowsky J (2008) Tropical deforestation, community forests, and protected areas in the Maya Forest. Ecol Soc 13:56

Brechin SR, Wilshusen PR, Fortwangler CL, West PC (2003) Contested nature. Promoting international biodiversity with social justice in the twenty-first century. State University of New York Press, New York

Brooks TM, Mittermeier RA, Mittermeier CG (2002) Habitat loss and extinction in the hotspots of biodiversity. Conserv Biol 16:909-923

Brooks TM, Mittermeier RA, da Fonseca GAB, Gerlach J, Hoffmann M, Lamoreux JF, Mittermeier CG, Pilgrim JD, Rodrigues ASL (2006) Global biodiversity conservation priorities. Science 313:58-61

Bruner AG (2001) Effectiveness of parks in protecting tropical biodiversity. Science 291:125-128

Busby JR (1991) BIOCLIM: a bioclimate analysis and prediction system. In: Margules CR, Austin MP (eds) Nature conservation: cost effective biological surveys and data analysis. CSIRO, Canberra, pp 64-68

Butchart SH et al (2010) Global biodiversity: indicators of recent declines. Science 328:1164-1168

Carpenter G, Gillison AN, Winter J (1993) DOMAIN: a flexible modeling procedure for mapping distributions of plants and animals. Biodivers Conserv 2:667-680

Carvajal S, Caso A, Downey P, Moreno A, Tewes M (2007) Conference 17-20 September 2007: programme and abstracts. Wildlife Conservation Research Unit, Oxford, p 118

Ceballos G, Pardo ED, Espinosa E, Flores-Villela O, García A, Martínez L, Martínez-Meyer E, Navarro A, Ochoa L. (2009) Zonas críticas y de alto riesgo para la conservación de la biodiversidad de México. In: CONABIO (ed) Capital natural de México, vol. II: Estado de conservación y tendencias de cambio. México, pp 675-600

CONABIO (2011) Águila real (Aquila crysaetos canadensis). In: Comisión Nacional de Áreas Naturales Protegidas and Comisión Nacional para el Conocimiento y Uso de la Biodiversidad (eds) Fichas de especies prioritarias. México

Corsi F, Dupré E, Boitani L (1999) A large-scale model of wolf distribution in Italy for conservation planning. Conserv Biol 13:150-159

De Oliveira TG (1998) Herpailurus yagouaroundi. Mamm Species 578:1-6

Diamond J (2002) Evolution, consequences and future of plant and animal domestication. Nature 418:700-707

Dillon A, Kelly MJ (2008) Ocelot home range, overlap and density: comparing radio telemetry with camera trapping. J Zool 275:391-398 
Diniz-Filho JAF, Bini LM, Rangel TF, Loyola RD, Hof C, Nogués-Bravo D, Araújo MB (2009) Partitioning and mapping uncertainties in ensembles of forecasts of species turnover under climate change. Ecography 32:897-906

Dirzo R, Raven PH (2003) Global state of biodiversity and loss. Annu Rev Environ Res 28:137-167

Don-Crider DL (1995) Population characteristics and home range dynamics of a black bear population in northern Coahuila, Mexico. MS thesis, Texas A\&M University, Texas

Duran-Zuazo VH, Rodriguez-Pleguezuelo CR, Francia-Martinez JR, Martin-Peinado FJ, Graaff J (2013) Land-use changes in a small watershed in the Mediterranean landscape (SE Spain): environmental implications of a shift towards subtropical crops. J Land Use Sci 8:47-58

Eastman JR, IDRISI S (2012) Clark University. Worcester, MA, USA

Eklund J, Arponen A, Visconti P, Cabeza M (2011) Governance factors in the identification of global conservation priorities for mammals. Phil Trans R Soc B 366:2661-2669

Elith J, Graham CH, Anderson RP (2006) Novel methods improve prediction of species' distributions from occurrence data. Ecography 29:129-151

Ellis EA, Porter-Bolland L (2008) Is community-based forest management more effective than protected areas? A comparison of land use/land cover change in two neighboring study areas of the Central Yucatan Peninsula, Mexico. Forest Ecol Manag 256:1971-1983

Escalante T, Sánchez-Cordero V, Morrone JJ, Linaje M (2007) Areas of endemism of mexican terrestrial mammals: a case study using species ecological niche modeling, parsimony analysis of endemicity and goloboff fit. Interciencia 32(3):151-159

Escalante-Pliego P, Navarro-Sigüenza AG, Peterson AT (1993) A geographic, historical, and ecological analysis of avian diversity in Mexico. In: Ramamoorthy TP, Bye R, Lot A, Fa J (eds) The biological diversity of Mexico: origins and distribution. Oxford University Press, New York, pp 281-307

Fahrig L (2001) How much habitat is enough? Biol Conserv 100:65-74

Faleiro FV, Loyola RD (2013) Socioeconomic and political trade-offs in biodiversity conservation: a case study of the Cerrado Biodiversity Hotspot, Brazil. Divers Dist 19:977-988

Faleiro FV, Machado RB, Loyola RD (2013) Defining spatial conservation priorities in the face of land-use and climate change. Biol Conserv 158:248-257

FAO (Food and Agriculture Organization of the United Nations) (2007) Gridded livestock of the world. In: Wint GGW, Robinson T (eds) Animal production and health division. FAO, Rome, p 131

Figueroa F, Sánchez-Cordero V (2008) Effectiveness of natural protected areas to prevent land use and land cover change in Mexico. Biodivers Conserv 17:3223-3240

Foley JA et al (2005) Global consequences of land use. Science 309:570-574

Folke C, Hahn T, Olsson P, Norberg J (2005) Adaptive governance of social-ecological systems. Annu Rev Environ Resour 30:441-473

Franklin J (2009) Mapping species distributions: spatial inference and predictions. Cambridge University Press, Cambridge, p 233

Fuller RA, Irvine KN, Devine-Wright P, Warren PH, Kevin J (2007) Gaston Psychological benefits of greenspace increase with biodiversity. Biol Lett 3:390-394

García-Frapolli E, Ramos-Fernandez G, Galicia E, Serrano A (2009) The complex reality of biodiversity conservation through Natural Protected Area policy: three cases from the Yucatan Peninsula, Mexico. Land Use Policy 26:715-722

Gaston KJ (2002) The structure and dynamics of geographic ranges. Oxford University Press, Oxford

Gaston AJ, Stockton SA, Smith JL (2006) Species-area relationships and the impact of deer-browse in the complex phytogeography of the Haida Gwaii archipelago (Queen Charlotte Islands) British Columbia. Ecoscience 13(4):511-522

Geist HJ, Lambin EF (2002) Proximate causes and underlying driving forces of tropical deforestation. Bioscience 52(2):143-150

Gilpin ME, Soul C (1986) Minimum viable populations: processes of species extinction. In: Soule ME (ed) Conservation Biology: the science of scarcity and diversity. Sinauer Associates, Sunderland, pp 19-34

Griffith B, Scott JM, Carpenter JW, Reed C (1989) Translocations as a species conservation tool: status and strategy. Science 245:477-480

Guisan A, Zimmerman NE (2000) Predictive habitat distribution models in ecology. Ecol Model 135:147-186

Hirzel AH, Gwenaëlle LL (2008) Habitat suitability modelling and niche theory. J Appl Ecol 45:1372-1381

Hirzel AH, Hausser J, Chessel D, Perrin N (2002) Ecological niche factor analysis: how to compute habitatsuitability maps without absence data? Ecology 83:2027-2036

Hoyo JD, Elliot A, Christie DA (2005) Handbook of the birds of the world (Volume 10): Cuckoo-shrikes to Thrushes. Lynx Editions, Barcelona, Spain 
Illoldi-Rangel P, Fuller T, Linaje M, Pappas C, Sánchez-Cordero V, Sarkar S (2008) Solving the maximum representation problem to prioritize areas for the conservation of terrestrial mammals at risk in Oaxaca. Divers Distrib 14:493-508

INEGI (2005) Conjunto de uso de suelo y vegetación a escala 1:250,000, Serie III. DDG-INEGI, México INEGI (2011) Conjunto de uso de suelo y vegetación a escala 1:250,000, Serie V. DDG-INEGI, México International Union for Conservation of Nature (IUCN) (2012) IUCN red list of threatened species. Version 2011.1

Jones M, MacLeod G (2004) Towards a regional renaissance? Reconfiguring and rescaling England's economic governance. Trans Inst Br Geogr 24:295-313

Kearney M, Porter W (2009) Mechanistic niche modelling: combining physiological and spatial data to predict species ranges. Ecol Lett 12:1-17

Klooster D, Masera O (2000) Community forest management in Mexico: carbon mitigation and biodiversity conservation through rural development. Glob Environ Chang 10:259-272

Knight AT, Cowling RM, Possingham HP, Wilson KA (2009) From theory to practice: designing and situating spatial prioritization approaches to better implement conservation action. In: Moilanen A (ed) Spatial conservation prioritization: quantitative methods and computational tools. Oxford University Press, Oxford, pp 249-259

Koleff P, Urquiza-Haas T, coords (2011) Planeación para la conservación de la biodiversidad terrestre en México: retos en un país megadiverso. Comisión Nacional para el Conocimiento y Uso de la Biodiversidad-Comisión Nacional de Áreas Naturales Protegidas, México, p 244

Lande R, Barrowclough GF (1987) Effective population size, genetic variation, and their use in population management. In: Soule M (ed) Viable populations for conservation. Cambridge University Press. Cambridge, Loh and Harmon, pp 87-124

Loh J, Harmon D (2005) A global index of biocultural diversity. Ecolo indic 5(3):231-241

Lopez-Feldman A, Taylor JE, Yúnez-Naude A (2011) Natural resource dependence in rural Mexico. Investig Econ 278:23-44

Loyola RD, de Oliveira G, Diniz-Filho JA, Lewinsohn TM (2008) Conservation of neotropical carnivores under different priorization scenarios: mapping species traits to minimize conservation conflicts. Divers Distrib 14:949-960

Madrid JA, Madrid HD, Funes SH, Lopez J, Botzoc R, Ramos A (1991) Reproductive biology and behavior Ornate Hawk-eagle in Tikal National Park. In: Whitacre DF, Burnham WA, Jenny JP (eds) Maya project: use of raptos as environmental indices for design and management of protect area sand for building local capacity for conservation in Latin America. The Peregrine Fund, Inc., Boise, Idaho, Progress Report 4, pp 93-113

Marmion M, Parviainen M, Luoto M, Heikkinen RK, Thuiller W (2009) Evaluation of consensus methods in predictive species distribution modeling. Divers Distrib 15:59-69

Mas JF (2005) Un método para combinar datos espectrales e información auxiliar en una red artificial neuronal. Anais XII Simposio Brasileiro de Sensoriamento Remoto, Goiânia, Brasil, pp 3543-3549

Mas JF et al (2004) Assessing land use/cover changes: a nationwide multidate spatial database for Mexico. Int J Appl Earth Obs 5:249-261

Miles L, Kapos V (2008) Reducing greenhouse gas emissions from deforestation and forest degradation: global land-use implications. Science 320:1454-1455

Mittermeier RA, Myers N, Robles GP, Mittermeier CG (eds) (1999) Hotspots. Earth's biologically richest and most endangered terrestrial ecoregions. CEMEX, Agrupacion Sierra Madre, Mexico

Moffett A, Sarkar S (2006) Incorporating multiple criteria into the design of conservation area networks: a minireview with recommendations. Divers Distrib 12:125-137

Moilanen A, Possingham HP, Wilson KA (2009) Spatial conservation prioritization: past, present and future. In: Moilanen A, Wilson KA, Possingham HA (eds) Spatial conservation prioritization: quantitative methods and computational tools. Oxford University Press, Oxford, pp 260-268

Moilanen A, Anderson BJ, Eigenbrod F et al (2011) Balancing alternative land uses in conservation prioritization. Ecol Appl 21:1419-1426

Muñiz-Lopéz R (2008) Revisión de la situación del Águila Harpía Harpia harpyja en Ecuador. Cotinga 29:42-47

Myers RA, Worm B (2003) Rapid worldwide depletion of predatory fish communities. Nature 423:280-283

Naughton-Treves L, Alvarez-Berríos NA, Brandon K, Bruner A, Holland M, Ponce C, Saenz C, Suarez L, Treves A (2005a) Expanding protected areas and incorporating human resource use: a study of 15 forest parks in Ecuador and Peru. Sustainability 2(2):32-44

Naughton-Treves L, Holland MB, Brandon, K (2005b) The role of protected areas in conserving biodiversity and sustaining local livelihoods. Annu Rev Environ Resour 30:219-252 
Navarro-Sigüenza AG, Lira-Noriega A, del Coro Arizmendi M, Berlanga H, Koleff P, García-Moreno J, Peterson AT (2011) Áreas de conservación para las aves: hacia la integración de criterios de priorización. In: Koleff P, Urquiza-Haas T (coords) Planeación para la conservación de la biodiversidad terrestre en México: retos en un país megadiverso. Comisión Nacional para el Conocimiento y Uso de la Biodiversidad-Comisión Nacional de Áreas Naturales Protegidas, México, pp 89-108

Noble IR, Dirzo R (1997) Forests as human-dominated ecosystems. Science 277:522-525

Noss RF, Harris LD (1986) Nodes, networks, and MUMS: preserving diversity at all scales. J Environ Manag 10:299-309

Ochoa-Ochoa L, Vázquez LB, Urbina-Cardona JN, Flores-Villela O (2011) Priorización de áreas para conservación de la herpetofauna utilizando diferentes métodos de selección. In: Koleff P, UrquizaHaas T (coords) Planeación para la conservación de la biodiversidad terrestre en México: retos en un país megadiverso. Comisión Nacional para el Conocimiento y Uso de la Biodiversidad-Comisión Nacional de Áreas Naturales Protegidas, México, pp 89-108

Ortega-Huerta MA, Peterson AT (2004) Modelling spatial patterns of biodiversity for conservation prioritization in North-eastern Mexico. Divers Distrib 10:39-54

Ostrom A (2010) Analyzing collective action. Agric Econ 41:155-166

Pérez-Vega A, Mas JF, Velázquez A, Vázquez L (2008) Land cover diversity patterns in Mexico based upon topographic features. Interciencia 33:88-95

Peterson AT, Nakazawa Y (2008) Environmental data sets matter in ecological niche modelling: an example with Solenopsis invicta and Solenopsis richteri. Global Ecol Biogeogr 17:135-144

Phillips SJ, Dudik M (2008) Modeling of species distributions with Maxent: new extensions and a comprehensive evaluation. Ecography 31:161-175

Phillips SJ, Anderson RP, Schapire RE (2006) Maximum entropy modeling of species geographic distributions. Ecol Model 190:231-259

Pressey RL, Bottrill MC (2008) Opportunism, threats and the evolution of systematic conservation planning. Conserv Biol 22:1340-1345

Purvis A, Gittleman JL, Cowlishaw G, Mace GM (2000) Predicting extinction risk in declining species. Proc R Soc Lond [Biol] 267:1947-1952

Raffestin C, Butler SA (2012) Space, territory, and territoriality. Environ Plan D 30:121-141

Rangel TF, Loyola RD (2012) Labeling ecological niche models. Nat Conserv 10:1-8

Rangel TF, Diniz-Filho JA, Araújo MB (2009) BIOENSEMBLES 1.0. Software for computer intensive ensemble forecasting of species distributions under climate change. Goiás, Madrid, Évora

Rodrigues ASL, Andelman SJ, Bakarr MI et al (2004) Effectiveness of the global protected area network in representing species diversity. Nature 428:640-643

Roura-Pascual N, Brorons L, Peterson AT, Thuiller W (2008) Consensual predictions of potential distributional areas for invasive species: a case study of Argentine ants in the Iberian Peninsula. Biol Invas 11:1017-1031

Salvatore M, Pozzi F, Ataman E, Haddleston B, Bloise M (2005) Mapping global urban and rural population distributions. Environment and natural resources working paper 24. Food and Agricultural Organizations of the United Nations. Roma

Sarukhán J (2011) Presentación. Planeación para la conservación de la biodiversidad terrestre en México: retos en un país megadiverso. In: Koleff P, Urquiza-Haas T (coords). Planeación para la conservación de la biodiversidad terrestre en México: retos en un país megadiverso. Comisión Nacional para el Conocimiento y Uso de la Biodiversidad-Comisión Nacional de Áreas Naturales Protegidas, México, pp 5

Sarukhán J, Urquiza-Haas T, Koleff P et al (2015) strategic actions to value, conserve, and restore the natural capital of megadiversity countries: the case of Mexico. BioScience 65:164

Scognamillo D, Maxit IE, Sunquist M, Polisar J (2003) Coexistence of jaguar (Panthera onca) and puma (Puma concolor) in a mosaic landscape in the Venezuelan llanos. J Zool 259:269-279

SEMARNAT (Secretaría del Medio Ambiente Recursos Naturales y Pesca) (2010) Norma Oficial Mexicana, NOM-059-ECOL-SEMARNAT-2001, Protección ambiental, especies nativas de México, Flora y Fauna Silvestre-Categorías de riesgo y especificación por su inclusión, exclusión o cambio-Lista de especies en riesgo. In: Diario Oficial de la Federación. 2nd edition. México, DF, pp 1-86

SEMARNAT (Secretaría del Medio Ambiente Recursos Naturales y Pesca), INEGI (Instituto Nacional de Estadística, Geografía e Informática), UNAM (Instituto de Geografía, Universidad Autónoma Nacional de México) (2001) Inventario Nacional Forestal. Escala 1:250,000. Instituto de Geografía, UNAM, México

Shaffer ML (1981) Minimum population sizes for species conservation. BioScience 31:131-134

Shaffer ML (1987) Minimum viable populations: coping with uncertainty. In: Soule ME (ed) Viable populations for conservation. Cambridge University Press, Cambridge, pp 69-86 
SIMBAD-INEGI (2010) http://sc.inegi.org.mx/cobdem/contenido-arbol.jsp

Simberloff D (1998) Flagships, umbrellas and keystones: is single-species management pass in the landscape era? Biol Conserv 83(3):247-257

Skutsch M, Turnhout E, Vijge MJ, Herold M, Wits T Besten J, Balderas TA (2014) Options for a national framework for benefit distribution and their relation to community-based and national REDD + monitoring. Forests 5:1596-1617

Smith FA, Brown JH, Haskell JP et al (2004) Similarity of mammalian body size across the taxonomic hierarchy and across space and time. Am Nat 163:672-691

Snyder SA (1993) Haliaeetus leucocephalus. Fire Effects Information System. U.S. Department of Agriculture, Forest Service. http://www.fs.fed.us/database/feis/

Soberón J, Jiménez R, Golubov J, Koleff P (2007) Assessing completeness of biodiversity databases at different spatial scales. Ecography 30:152-160

Soulé ME (1985) What is conservation biology? BioScience 35(11):727-734

Stockwell DRB, Noble IR (1992) Induction of sets of rules from animal distribution data: a robust and informative method of data analysis. Math Comput Simul 32:249-254

Sunquist M, Sunquist F (2002) Wild cats of the world. University of Chicago Press, Chicago

Swets JA (1995) Signal detection theory and ROC analysis in psychology and diagnostics: collected papers. Lawrence Erlbaum Associates

Téllez O, Hutchinson MA, Nix HA, Jones P (2011) Desarrollo de coberturas digitales climáticas para México. In: Sánchez RG, Ballesteros BC, Pavón PN (eds) Cambio Climático: aproximaciones para el estudio de su efecto sobre la biodiversidad. Universidad Autónoma del Estado de Hidalgo, México, pp 15-112

Tilman D, Reich PB, Knops J, Wedin D, Mielke T, Lehman C (2001) Diversity and productivity in a longterm grassland experiment. Science 294:843-845

Tobón W, Urquiza-Haas T, Ramos-Fernández G, Calixto-Pérez E, Alarcón J, Kolh M, Koleff P (2012) Prioridades para la conservación de los primates en México. In: Comisión Nacional para el conocimiento y Uso de la Biodiversidad-Asociación Mexicana de Primatología. A.C.-Comisión Nacional de Áreas Naturales Protegidas. Ciudad de México, México, pp 1-7

Urquiza-Haas T, Cantú C, Koleff P, Tobón W (2011) Caracterización de las ecorregiones terrestres: diversidad biológica, amenazas y conservación. In: Koleff P, Urquiza-Haas T (coords). Planeación para la conservación de la biodiversidad terrestre en México: retos en un país megadiverso. Comisión Nacional para el Conocimiento y Uso de la Biodiversidad-Comisión Nacional de Áreas Naturales Protegidas, México, pp 21-58

Urquiza-Haas T, Tobón W, Koleff P (2011) Sitios prioritarios para la conservación de mamíferos terrestres: evaluación de los criterios de selección de indicadores. In: Koleff P, Urquiza-Haas T (coords). Planeación para la conservación de la biodiversidad terrestre en México: retos en un país megadiverso. Comisión Nacional para el Conocimiento y Uso de la Biodiversidad-Comisión Nacional de Áreas Naturales Protegidas, México, pp 131-149

USGS (United States Geological Survey) (2007) Shuttle radar topography mission (SRTM) 3-arc second ARTM Format Documentation. USGS/NASA. http://edc.usgs.gov/products/elevation/srtmbil.html. Accessed 3 December 2015

Velázquez A (2012) El contexto geográfico de los lagomorfos de México. Therya 3:223-238

Velázquez A, Bocco G, Torres A (2001) Turning scientific approaches into practical conservation actions: the case of Comunidad Indígena de Nuevo San Juan Parangaricutiro, México. Environ Manag 5:655-665

Velázquez A, Mas JF, Palacio JL, Bocco G (2002) Land cover mapping to obtain a current profile of deforestation in México. Unasylva 210:37-40

Velázquez A, Fregoso A, Bocco G, Cortés G (2003) The use of a landscape approach in Mexican forest indigenous communities to strengthening long term forest management. Interciencia 28(11):632-638

Velázquez A, Cué-Bär EM, Larrazábal A, Sosa N, Villaseñor JL, McCall M, Ibarra-Manríquez G (2009) Building participatory landscape-based conservation alternatives: a case study of Michoacán, México. Appl Geog 29:513-526

Velázquez A, Mas JF, Bocco G, Palacio-Prieto JL (2010) Mapping land cover changes in Mexico, 1976-2000 and applications for guiding environmental management policy. Singap J Trop Geogr 31:152-162

Walker B, Holling CS, Carpenter CR, Kinzig A (2004) Resilience, adaptability and transformability in social-ecological systems. Ecol Soc 9:5 